\title{
Tracing glacial meltwater from the Greenland Ice Sheet to the ocean using gliders
}

\author{
Katharine R. Hendry ${ }^{1}$, Nathan Briggs ${ }^{2}$, Stephanie Henson ${ }^{2}$, Jacob Opher ${ }^{3,4}$, \\ J. Alexander Brearley ${ }^{3}$, Michael P. Meredith ${ }^{3}$, Melanie J. Leng ${ }^{5,6}$, Lorenz \\ Meire $^{7,8}$ \\ ${ }^{1}$ School of Earth Sciences, University of Bristol, Wills Memorial Building, Queens Road, Bristol, BS8 \\ 1RJ, UK \\ ${ }^{2}$ National Oceanography Centre, European Way, Southampton, SO14 3ZH, UK \\ ${ }^{3}$ British Antarctic Survey, High Cross, Madingley Road, Cambridge, CB3 0ET, UK \\ ${ }^{4}$ School of Environmental Sciences, University of East Anglia, Norwich Research Park, Norwich, NR4 \\ $7 \mathrm{TJ}, \mathrm{UK}$ \\ ${ }^{5}$ National Isotope Environmental Facility, British Geological Survey, Keyworth, Nottingham, NG12 5GG, \\ UK \\ ${ }^{6}$ Centre for Environmental Geochemistry, School of Biosciences, Sutton Bonington Campus, University of \\ Nottingham, Loughborough, LE12 5RD, UK \\ ${ }^{7}$ Department of Estuarine and Delta Systems, Royal Netherlands Institute for Sea Research, Yerseke, The \\ Netherlands \\ ${ }^{8}$ Greenland Climate Research Centre, Greenland Institute of Natural Resources, Nuuk, Greenland
}

\section{Key Points:}

- We report bio-optical data from a glider deployment off SW Greenland

- High optical backscatter is associated with both high-chlorophyll surface waters and coastal water mass

- Meltwaters enriched in fluorescent dissolved organic matter cross the strong boundary current into the Labrador Sea

Corresponding author: Katharine Hendry, k.hendry@bristol.ac.uk

This article has been accepted for publication and ${ }^{-1}$ undergone full peer review but has not been through the copyediting, typesetting, pagination and proofreading process, which may lead to differences between this version and the Version of Record. Please cite this article as doi: 10.1029/2021JC017274. 


\begin{abstract}
The Greenland Ice Sheet (GrIS) is experiencing significant mass loss and freshwater discharge at glacier fronts. The freshwater input from Greenland will impact the physical properties of adjacent coastal seas, including important regions of deep water formation and contribute to global sea level rise. However, the biogeochemical impact of increasing freshwater discharge from the GrIS is less well constrained. Here, we demonstrate the use of bio-optical sensors on ocean gliders to track biogeochemical properties of meltwaters off southwest Greenland. Our results reveal that fresh, coastal waters, with an oxygen isotopic composition characteristic of glacial meltwater, are distinguished by a high optical backscatter and high levels of fluorescing dissolved organic matter (FDOM), representative of the overall coloured dissolved organic matter pool. Reconstructions of geostrophic velocities are used to show that these particle and FDOM-enriched coastal waters cross the strong boundary currents into the Labrador Sea. Meltwater input into the Labrador Sea is likely driven by mesoscale processes, such as eddy formation and local bathymetric steering, in addition to wind-driven Ekman transport. Ocean gliders housing bio-optical sensors can provide the high-resolution observations of both dissolved and particulate glacially-derived material that are needed to understand meltwater dispersal mechanisms and their sensitivity to future climatic change.
\end{abstract}

\title{
Plain Language Summary
}

The Intergovernmental Panel on Climate Change Special Report on the Oceans and Cryosphere in a Changing Climate recently reported that the Greenland Ice Sheet is extremely likely to experience significant mass loss in coming decades. The freshwater from the melting ice sheet and glaciers will change the density of the surrounding seawater, with major implications for global ocean circulation and will contribute to sea level rise. The meltwater input could also change the chemistry of the ocean, but the extent to which this is the case is poorly understood. One of the challenges is to obtain high-resolution observations of ocean physical and chemical properties around Greenland. Here, we show that such observations are possible using autonomous underwater vehicles. Our results show that fresh, coastal waters, with the chemical fingerprint of glacial meltwater, can be picked out using widely available optical sensors. Reconstructions of ocean currents from the glider velocities show that these particle and organic matter rich waters can cross from the coastal waters into the open ocean, potentially influencing marine biological production on a wide geographical scale.

\section{Introduction}

The northern high-latitude regions are undergoing some of the fastest environmental changes seen globally in recent decades (Meredith et al., 2019). The Greenland Ice Sheet (GrIS) is experiencing significant mass loss via ice discharge at glacier fronts and surface melting (Enderlin et al., 2014; Felikson et al., 2017; van den Broeke et al., 2017; Shepherd et al., 2020). The oceans surrounding the GrIS are sensitive to the release of glacial meltwaters, as the resulting freshening may influence the density structure and stratification in regions where deep water-masses are formed (Carmack et al., 2016; Proshutinsky et al., 2015; Yang et al., 2016). Subglacial runoff is also characterised by a high concentration of organic matter and inorganic nutrients in both dissolved and particulate form, especially iron and dissolved silicon (Bhatia et al., 2013; Hawkings et al., 2014, 2017; Meire et al., 2016). Tracking these meltwaters and glacial particulate inputs is key to understanding not only physical changes in the oceans but potential shifts in regional nutrient supply and marine ecosystem structure. However, nutrients from meltwaters are trapped abiologically and biologically within fjord systems, and the extent to which glaciallyderived, nutrient-rich material reaches the coastal shelf seas and crosses boundary currents into the open ocean is not sufficiently established (Hopwood et al., 2015, 2020). Fur- 
thermore, the role of benthic cycling in supplying nutrients to fjords and glaciated margins in the high-latitudes, relative to direct meltwater sources, is not fully understood (Koziorowska et al., 2018; Zaborska et al., 2018; Ng et al., 2020). Recent evidence using a variety of physical and geochemical approaches revealed that a significant proportion of freshwater and glacially derived material extends off the southwest (SW) Greenland shelf into the region of the boundary current (Hendry et al., 2019). Satellite observations and ecosystem models also support a link between glacial melt and summer phytoplankton blooms in this area (Arrigo et al., 2017; Oliver et al., 2018).

There are a number of different methodologies for tracking meltwaters and sediment inputs in coastal seas. Ship-deployed sensors can be used to trace changes in physical and bio-optical properties associated with meltwaters (Pan et al., 2019). Geochemical methods can be used, when different inputs represent different compositional endmembers, allowing relative contributions of glacial vs. non-glacial sources to be calculated by mass balance. For example, dissolved oxygen concentrations, alkalinity, or oxygen isotope composition $\left(\delta^{18} \mathrm{O}\right)$ of seawater can be used together with salinity variations to calculate the relative contribution of meteoric sources, dominated by glacial meltwater in glaciated margins, versus sea-ice to the freshwater budget (Jenkins, 1999; Meredith et al., 2008; Hendry et al., 2018; Biddle et al., 2015). Remote sensing of meltwaters, and their biogeochemical impacts, is also possible using satellite ocean colour algorithms in combination with regional modelling (McGrath et al., 2010; Arrigo et al., 2017).

However, there are a number of limitations surrounding both ship-based and remote sensing approaches to tracking meltwater, including ship accessibility and cost, seasonal coverage, and weather dependence.

Autonomous, underwater gliders provide solutions to a number of these limitations. These gliders are ideal for high-latitude coastal work, providing continuous, direct measurements from beneath the sea-surface, including under harsh weather conditions and in regions that can be inaccessible by larger ships (Fan et al., 2013; Rudnick, 2016; Kohut et al., 2013; Carvalho et al., 2016). Gliders can be fitted with a wide array of sensors, allowing the collection of high-resolution physical and bio-optical measurements, and - when deploying multiple vehicles - can be used to obtain a more synoptic view of the physical and biological processes active in the region of interest (Meyer, 2016). Here, we present the first bio-optical glider observations off the SW coast of Greenland and show how they can be used together with shipboard and Biogeochemical-Argo (BGCArgo) float data to track the dissolved and particulate inputs from GrIS meltwaters into the Labrador Sea.

\section{Methods}

\subsection{Field methodology}

Two Slocum gliders (units 331 Coprolite and 439 HSB) were deployed during RRS Discovery expedition DY081 on July 17 th 2017 at $62.9^{\circ} \mathrm{N}, 52.6^{\circ} \mathrm{W}$, approximately $40 \mathrm{~km}$ off the Greenland shelf break, travelled North along the coast in a zig-zag pattern between the shelf and deep waters, and were recovered 8 days later from $63.7^{\circ} \mathrm{N}, 53.1^{\circ} \mathrm{W}$ and $62.9^{\circ} \mathrm{N}, 52.7^{\circ} \mathrm{W}$ respectively on July 24th 2017 (Fig. 1, (Hendry et al., 2021)). Gliders profiled from the surface to $1000 \mathrm{~m}$, except during the two excursions onto the shelf, once south and once north of the Godthäb Trough, where they followed the bathymetry. Each glider track was divided into three on-off shelf sections to quantify the temperature, salinity, chlorophyll-a (Chl a) and FDOM across the boundary current system, which runs parallel to the shelf break. The mean position of each profile is shown using the inverted triangles at the top of each of the section figures (Fig. 2,3 and 5). In brief, the mean distance between profiles for glider 331 was $0.52 \mathrm{~km}, 0.47 \mathrm{~km}$ and $0.37 \mathrm{~km}$ for sections 1,2 and 3 respectively. For glider 439 , the equivalent distances were $0.56 \mathrm{~km}, 1.03$ $\mathrm{km}$ and $1.37 \mathrm{~km}$. Note the spacing is much closer for the shallower dives on the shelf $(0.1-$ $0.2 \mathrm{~km})$ compared with in the deep part of each section $(3-4 \mathrm{~km})$. Each of the on-shelf 
glider profiles, generally in 100-200 m water depth, took around 10-20 minutes to complete, while a $1000 \mathrm{~m}$ off-shelf profile took around 90 minutes. Each glider was fitted with a pumped CTD and bio-optical sensors (WET Labs puck; for configuration see Supplementary Information Table S1). These bio-optical sensors measure optical backscattering (in the form of the volume scattering function), chlorophyll fluorescence, and UV fluorescence for fluorescing dissolved organic matter (FDOM, see Supplementary Text S1), a subset of coloured dissolved organic matter (CDOM).

Prior to deployment, a conductivity-temperature-depth (CTD) profiler and rosette was deployed for calibration purposes, and salinity was calibrated against bottle measurements (Hendry et al., 2019). Glider temperature and salinity (T and S, here corrected for thermal lag) showed no significant offsets when compared to the shipboard CTD data. Whilst a CTD was not deployed upon glider recovery for verification, a comparison of $\mathrm{T} / \mathrm{S}$ data between dive profiles from early and late in the deployment do not show any significant offset (Supplementary information, Fig. S2), which strongly suggests that there was no significant sensor drift during the deployment.

Glider data and positional information can be used to determine current velocities along the glider path during its mission. Calculating the full velocity field requires an accurate reference velocity estimate. While the glider itself does not provide this, careful processing of the depth-averaged velocities between pairs of glider surfacings yields a depth-integrated transport field against which the geostrophic shear from the glider $\mathrm{T} / \mathrm{S}$ can be referenced. The depth-averaged velocities were first corrected for surface drift (Merckelbach et al., 2010), and then detided using the barotropic tide solution obtained from the Oregon State University Model (Egbert \& Erofeeva, 2002), as instantaneous velocities are heavily influenced by tidal motions not relevant to the geostrophic field. To remove other sources of high-frequency variability, the detided velocities were then smoothed using a Laplacian spline interpolant over $6 \mathrm{~km}$, with gridding at $2 \mathrm{~km}$ in the horizontal and $5 \mathrm{~m}$ in the vertical, from a baseline at $0 \mathrm{~km}$ oriented perpendicular to the shelf break. There were typically up to 10 profiles per $2 \mathrm{~km}$ on the shelf, and one profile per $2 \mathrm{~km}$ in the deep region offshore. This gridding allows for the removal of highfrequency variability in the velocity field not associated with geostrophic transports (e.g. inertial motions). Finally, the $\mathrm{T}$ and $\mathrm{S}$ fields were identically filtered before using the depthaveraged velocities to reference the T- and S-derived geostrophic shear.

The bio-optical properties were derived using the calibration curves from the manufacturer. The optical particle backscattering coefficient $\left(\mathrm{b}_{b p}\right.$, in $\left.\mathrm{m}^{-1}\right)$ was calculated by firstly correcting the volume scattering function (at an angle of $124^{\circ}$ and at a wavelength of $650 \mathrm{~nm}$, in $\mathrm{m}^{-1} \mathrm{sr}^{-1}$ ) for scattering due to seawater and, secondly, integrating across all backward angles using an assumed angular dependency for marine particles (Zhang et al., 2009; Sullivan et al., 2013).

The chlorophyll data from each profile were dark-corrected by subtracting from each value the median chlorophyll below $300 \mathrm{~m}$ (Thomalla et al., 2017). Quenching was identified from all daylight profiles (from Nuuk sunrise to sunset plus 2.5 hours) and corrected based on published methods (Swart et al., 2015). Briefly, the maximum Chl a:b $b_{b p}$ ratio within the mixed layer, and the depth of this maximum, were found for each profile; all chlorophyll data above this depth were corrected for quenching by multiplying the maximum Chl $a: b_{b p}$ with the corresponding $b_{b p}$ value (Supplementary Information Figure S3). Note that this approach assumes that the particle population affected by quenching has a constant $\mathrm{Chl} \mathrm{a}: \mathrm{b}_{b p}$ ratio.

Seawater samples were collected for $\delta^{18} \mathrm{O}$ analysis, using standard Niskin bottles attached to the CTD rosette on the RRS Discovery during expedition DY081 across a grid within the glider transit area. The $\delta^{18} \mathrm{O}$ measurements were made using the $\mathrm{CO}_{2}$ equilibration method with an Isoprime 100 mass spectrometer plus Aquaprep device at the British Geological Survey Stable Isotope Facility. 


\subsection{Data analysis and interpretation methodology}

\subsubsection{Meltwater input calculations}

We can use simple mass balance equations (Equations 1 and 2) to calculate glacial meltwater input, assuming the endmember salinity of glacial meltwater is zero (Biddle et al., 2015):

$$
S_{o}=S_{a} A+S_{m w}(1-A)
$$

$$
A=\frac{S_{o}}{S_{a}}
$$

where $\mathrm{S}_{o}$ is the observed salinity, $\mathrm{S}_{a}$ is the average salinity of Subpolar Mode Water (SPMW) in the area (34.88), $\mathrm{S}_{m w}$ is the salinity of meltwater (0), A is the fraction of seawater, and (1-A) is fraction of meltwater present. However, these calculations ignore the potential contribution of freshwater from other sources including sea ice within waters that originate in the East Greenland Current and that flow around the southern tip of Greenland (Cox et al., 2010). The contribution from non-glaciated runoff to the total freshwater flux is low and can be considered negligible (Bamber et al., 2018). Another approach to calculating the proportion of meltwater that can be used to validate the approach in Equations 1-2 is to use a mass balance calculation (Equations 3 - 5) that incorporates both salinity and oxygen isotope $\left(\delta^{18} \mathrm{O}\right)$ measurements (Meredith et al., 2008).

$$
F_{s p m w}+F_{m e}+F_{s i}=1
$$

$$
F_{s p m w} S_{s p m w}+F_{m e} S_{m e}+F_{s i} S_{s i}=S_{o}
$$

$$
F_{s p m w} \delta_{s p m w}+F_{m e} \delta_{m e}+F_{s i} \delta_{s i}=\delta_{o}
$$

where $\mathrm{F}_{s p m w}, \mathrm{~F}_{m e}, \mathrm{~F}_{s i}$ are the calculated fractions of SPMW, meteoric and sea ice melt respectively (SPMW being the chosen ocean endmember), which sum to 1 by definition. The result is clearly dependent on the exact choice of endmembers for salinity $\left(\mathrm{S}_{s p m w}, \mathrm{~S}_{m e}, \mathrm{~S}_{s i}\right)$ and $\delta^{18} \mathrm{O}\left(\delta_{s p m w}, \delta_{m e}, \delta_{s i}\right)$ for the Irminger Water, meteoric and sea ice melt respectively. $\mathrm{S}_{o}$ and $\delta_{o}$ are the observed salinity and $\delta^{18} \mathrm{O}$ of each sample.

Pearson correlation coefficients of the different bio-optical parameters relative to the calculated meltwater fractions were derived. Given the likelihood of autocorrelations within the timeseries datasets, the significance of the correlation coefficients were assessed taking into consideration the number of effective degrees of freedom. For $\mathrm{N}$ measurements, the autocorrelation, $\mathrm{C}$, and the lags at which the correlations were computed, were assessed using a biased estimator by calculating the normalised cross-correlation of the parameters such that the autocorrelations at zero lag equal unity. Then the decorrelation scale, $\tau$, and number of effective degrees of freedom, $\mathrm{N}_{e f f}$, were computed using Equations 6 and 7 respectively. The $\mathrm{r}$ values at both $95 \%$ and $99 \%$ significance levels, $\mathrm{r}_{\text {sig }}$, 
were then computed for the given values of $\mathrm{N}_{e f f}$ using a Gaussian error function, erf, for a given significance level (s, Equation 8).

$$
\tau=\sum_{n=-N}^{N} C(n) \delta t
$$

$$
N_{e f f}=\frac{N}{\tau}-2
$$

$$
r_{s i g}=\operatorname{erf}^{-1}(s) \sqrt{\frac{2}{N_{e f f}}}
$$

\subsubsection{Argo float data and analytical methods}

Fluorescing dissolved organic matter, FDOM, comprises only a subset of coloured organic matter, CDOM, which absorbs in the visible wavelengths. As the nature of organic matter may vary spatially and temporally, for example as a result of differences in the relative contribution of marine versus terrestrial organic matter (Stedmon \& Markager, 2001) or sea-ice presence (Stedmon et al., 2007), it is non-trivial to determine to what extent FDOM measurements relate to CDOM more broadly, as assessed from absorption data.

To assess regional significance and whether our FDOM data represents CDOM more generally, we can analyse the diffuse attenuation coefficient of downwelling light, $\mathrm{K}_{d}$, at 380,412 , and $490 \mathrm{~nm}$ using a spatially and temporally broader dataset from ten BGCArgo floats in the Labrador and Irminger Seas (from Coriolis : ftp://ftp.ifremer.fr/ifremer/argo). Values of $\mathrm{K}_{d}$ are measured in units of inverse meters, and, in the visible wavelengths are dominated by absorption due to Chlorophyll, CDOM, and detrital matter. In order to isolate the contribution of CDOM from Chl and any phytoplankton-associated detrital matter, we used a type-I linear regression to find and remove the first-order dependency of $\mathrm{K}_{d}$ on Chl fluorescence for each float and for each wavelength of $\mathrm{K}_{d}$, resulting in a $\mathrm{K}_{d}$ anomaly. For each float and each wavelength, the relationship between this $\mathrm{K}_{d}$ anomaly and FDOM was determined, again by type-I linear regression.

\section{Results}

\subsection{Physical Oceanography}

The CTD and glider T and S profiles are consistent with known regional hydrography. Coastal, surface water (in upper $100 \mathrm{~m}$ ) that consists of modified Arctic Water/meltwater, overlies warmer North Atlantic Water (temperature $>3^{\circ} \mathrm{C}$, salinity $<34.5$; Fig. 2) with a temperature maximum at approximately $400 \mathrm{~m}$ water depth, most likely representing the core of Irminger Water (McCartney \& Talley, 1982) or upper Subpolar Mode Water (uSPMW) (Rysgaard et al., 2020). The orientation and the velocity maximum of the geostrophic current between glider sections 2 and 3 (approximately $30-40 \mathrm{~cm} \mathrm{~s}^{-1}$ ) are in close agreement with those calculated from CTD stations referenced to lowered Acoustic Doppler Current Profiler (ADCP) along Godthäb Trough (Hendry et al., 2019).

The mass balance for the seawater samples collected during DY081 assumed endmember values that have been presented elsewhere (Hendry et al., 2019) and indicates that the surface waters over the shelf comprise up to 5-6\% meteoric water, which can 
be assumed to be dominated by glacial meltwater in this region, and a smaller proportion of freshwater input from sea ice $(<1.5 \%)$. Using the glider data only (Equations 12 ), the calculated meteoric water inputs range from approximately $5 \%$ on the shelf to the south of the study area, to $2-3 \%$ off the shelf (Fig. 3). The meteoric (i.e. meltwater) proportions calculated for the bottle samples collected on the ship within the Nuuk area using the two methods (Equations 1-2 and Equations 3-5) correlate very strongly $(\mathrm{r}=0.99, \mathrm{p}<0.001, \mathrm{n}=144)$ with a Root Mean Square error (RMS) of $0.6 \%$. These results indicate that our simple mass balance calculation from Equations 1-2 based on the glider data are a reasonable indication of relative meltwater input.

\subsection{Bio-optical properties}

The chlorophyll (Chl a) fluorescence data show a strong subsurface concentration maximum (Fig. 3), with typical concentrations of $4 \mathrm{mg} \mathrm{m}^{-3}$, or greater, at 10-20 m, matching well with bottle pigment data from DY081, with mean extracted Chl a concentrations in the top $20 \mathrm{~m}$ of $5.5 \mathrm{mg} \mathrm{m}^{-3}$ (standard deviation $3.4 \mathrm{mg} \mathrm{m}^{-3}$ ) (Hendry et al., 2019). The shallow chlorophyll maximum is consistent with the surface water stratification and relatively low light penetration (shipboard sensors indicate the $1 \%$ photosynthetically active radiation depth of approximately $20-30 \mathrm{~m}$ ). The optical particle backscattering coefficient $\left(b_{b p}\right)$ shows elevated values in the subsurface, at least $4 \times 10^{-3} \mathrm{~m}^{-1}$ or more down to $20-50 \mathrm{~m}$. In contrast, UV FDOM shows elevated concentrations $(>1.8 \mathrm{ppb}$ over shelf, 1.6-1.7 ppb off shelf) from the subsurface down to 100-200 m (Fig. 3), displaying similar spatial and temporal distributions to cold, fresh surface waters. There is a reduced FDOM concentration in the near surface, likely due to photo-degradation (Mopper et al., 2015), which acts as a major sink of CDOM in the ocean (Fig. 3).

The bio-optical properties of the water show significant relationships with the presence of meltwater, as calculated from equations 1 and 2. The strongest correlation is observed for FDOM, in particular between 50 and $200 \mathrm{~m}$ water depth (Table 1). The relationship between meltwater percentage and FDOM breaks down at the very surface, with a switch from a positive to a negative correlation at meltwater concentrations greater than approximately $3.5 \%$, as a result of FDOM breakdown by photoreactions (Mopper et al., 2015). The relationship between FDOM and meltwater shows that there is a secondorder dependence on latitude that is consistent between the two gliders, potentially revealing an along-shelf gradient with a higher FDOM concentration in the more northerly freshwater sources (Fig. 4). The Chl a and $\mathrm{b}_{b p}$ observations show less significant correlations with meltwater (Table 1), which likely reflects the multiple transported and in situ sources of chlorophyll, and biological and abiological particles detected by backscatter.

The relationship between $\mathrm{K}_{d} 380$ and salinity was negative for all Argo floats, with correlations strongest for individual floats that encountered the greatest range of salinities ( $\mathrm{r}$ ranging between 0.22 and 0.87 ). The average regression slopes of $\mathrm{K}_{d}$ on $\mathrm{Chl} \mathrm{flu}-$ orescence for the Argo float data are reported in the supplementary information (Fig. $\mathrm{S} 8$ ). We found significant positive relationships between our $\mathrm{K}_{d}$ anomalies and FDOM, and the slope of this relationship decreased with increasing wavelength, approximately following a negative exponential with coefficient -0.017 , consistent with the typical spectral absorption of CDOM (Helms et al., 2008). This finding mirrors previous broaderscale findings (Organelli et al., 2017) and indicates that our FDOM data are representative of the broader CDOM pool, strengthening the link between our study and studies that only report CDOM absorption data. 


\section{Discussion}

\subsection{Factors affecting the backscatter distribution}

Biological material (living and dead algal cells) is likely to contribute to the particulate material in the water column that results in the observed optical backscatter distribution, especially in the near-surface waters. There is a strong correlation between quenching-corrected $\mathrm{Chl} a$ and $\mathrm{b}_{b p}$ in surface and subsurface waters $<100 \mathrm{~m}$ (linear correlation $\mathrm{r}=0.89, \mathrm{r}_{\text {sig }}=0.77 ; 99 \%$ significance level; $\mathrm{N}_{\text {eff }}=9$ ). This observation is consistent with previous findings from glider data that indicate that algae contribute to the particulate load in open ocean regions of the Labrador Sea (Frajka-Williams et al., 2009) and other high-latitude regions (Cetinić et al., 2015; Carvalho et al., 2016), despite differing optical behaviours between different algal types (Schofield et al., 2015).

However, visual inspection of the glider bio-optical data suggests that the meltwaterrich shelf waters have more particulates not attributable to phytoplankton. When high Chl a datapoints are removed $\left(>0.2 \mathrm{mg} \mathrm{m}^{-3}\right)$, the relationship between T,S and $\mathrm{b}_{b p}$ shows that fresher, colder waters are generally associated with higher particulate content (Fig. 5), suggesting that particles associated with the coastal waters are likely an important source of optical backscatter. Another potential method to illustrate the abiological input of particulates is to calculate the anomaly in the relationship between chlorophyll and backscatter for the shelf regions. To do so, we constructed a linear regression model between backscatter and chlorophyll for the deep profiles only (>900 m water depth). We then used this model to calculate the expected backscatter for the shallow profiles $(<100 \mathrm{~m}$ water depth) and associated anomaly with observations. Whilst this anomaly is centred around zero for the deeper profiles, it is offset towards positive values in shallower sites (Fig. 5), suggesting these shallower sites are characterised by a different chlorophyllto-backscatter relationship. This different bio-optical characterisation could be driven by changes in plankton community (biological factors that could create a positive $\mathrm{b}_{b p}$ anomaly include: less chlorophyll per cell, greater $b_{b p}$ per cell, or a lower ratio of autotrophic plankton to non-chlorophyll-bearing heterotrophic plankton) or because there is an additional source of particulates other than algae.

The most likely candidates for this source are sediments transported by glacial meltwater and resuspended shelf sediments. Glacial meltwaters are enriched in fine, particulate matter from a combination of subglacial weathering processes and entrainment of proximal sediments in buoyant meltwater plumes (Chu et al., 2012; Andrés et al., 2020). Satellite observations indicate that the areal extent of such sediment-enriched plumes off Greenland correlate with melt extent (Tedstone \& Arnold, 2012), indicating a close association between particulate and meltwater supply. Furthermore, meltwater-derived waters have been shown in both Greenlandic and Antarctic fjords to influence backscatter in glider and ship-deployed sensor data (Holinde \& Zielinski, 2015; Pan et al., 2019). However, it is also possible that the elevated backscatter is a result of sediment resuspension on the shelf, in particular in response to storm disturbance (with wind speeds up to $15 \mathrm{~ms}^{-1}$ during Julian Day 199) during the glider deployment, as has been observed in other studies (Glenn et al., 2008; Miles et al., 2015). This interpretation is supported by depth profiles from nearby ship-board CTD casts, which indicate an increase in turbidity in the bottom 100-150 m within the main trough that cuts across the shelf and that was occupied by the gliders (Supplementary Information, Fig. S7). The increase in backscatter anomaly and turbidity with depth (Fig. 5) suggests that there could be a contribution from resuspended material, a phenomenon also observed near the Dotson Ice Shelf in Antarctica (Miles et al., 2016).

In summary, our results indicate that there is a complex relationship between meltwater and water column $\mathrm{b}_{b p}$, which is likely a result of multiple controls on backscatter from particles characterised by different optical properties and from different sources, including in situ algal communities and resuspension, in addition to potential glacial inputs. 


\subsection{Origin and fate of coloured dissolved organic matter}

\subsubsection{Source of FDOM in coastal waters}

Below the surface mixed layer, the strongest spatial correlation with FDOM is with the prevalence of cold, fresh waters (Fig. 3 and 4), indicating that meteoric input plays a strong role in CDOM supply. However, there is also a relatively weak correlation between FDOM and Chl a in our data indicating, as with the optical backscatter, that in situ biology could be a secondary source of CDOM to the water column. For example, Phaeocystis blooms from the Labrador Sea have been observed to produce quantities of mucilaginous matrix that could contribute to the DOM pool either directly or via bacterial decomposition (Alderkamp et al., 2007; Wassmann et al., 1990). The weak correlation between FDOM and $\mathrm{Chl}$ a in our data likely arises because dissolved organic matter has multiple sources (terrestrial and open-ocean) and can have much longer residence time than $\mathrm{Chl}$ a in the ocean. A sedimentary source of FDOM is also possible (Luek et al., 2017). However, a sediment source is unlikely to result in a strong correlation between FDOM and meteoric water, as resuspension will show stronger associations with either tidal or wind-driven deep mixing (Crusius et al., 2017), rather than meltwater inputs.

Given the statistically significant relationship between meteoric water and FDOM sensor measurements, glacial meltwaters are a strong contender for the CDOM source, given that meltwaters contain dissolved organic carbon (Hood et al., 2015; Vick-Majors et al., 2020). However, existing field measurements indicate highly variable CDOM distributions both within and between Greenlandic fjords, potentially resulting in heterogeneous inputs from different upstream fjords, and secondary variability in the relationship between CDOM and salinity in the coastal ocean (Fig. 4). Although icebergs can release CDOM (Biddle et al., 2015), marine-terminating glacial fjords tend to have relatively low CDOM concentrations relative to land-terminating glacial fjords, which can be characterised by higher CDOM concentrations especially at the point of freshwater inflow (Lund-Hansen et al., 2010; Holinde \& Zielinski, 2016). In addition, deglaciated watersheds tend to have higher dissolved organic matter concentrations than glaciallyfed rivers, and are derived more from terrestrial vegetation and soils rather than in situ algal biomass (Pain et al., 2020), which could contribute further CDOM to the ocean. While some fjords tend to show inverse relationships between CDOM and salinity (indicating a freshwater source) others show a positive relationship (indicating a marine source) or no relationship at all (Murray et al., 2015; Mascarenhas \& Zielinski, 2019). In Godthäbsfjord, a fjord system to the north of our study area fed by a large marine-terminating glacier in addition to a number of glacially-fed rivers, previous studies have revealed either a weak positive or lack of relationship between CDOM and salinity (Murray et al., 2015; Mascarenhas \& Zielinski, 2019). However, further work is required to elucidate the role of photochemical reactions in shallow coastal waters, and their impact on the relationship between meltwaters and CDOM content at the fjord surface.

Arctic-derived freshwater is likely an important source of CDOM in fjords and coastal regions in Northeast Greenland as a result of continental input from large Arctic rivers and shelf-sediment interaction being transported southwards by the East Greenland Current; however, this particular input is likely diminished as the waters flow into the West Greenland Current (Stedmon et al., 2015; Murray et al., 2015; Dmitrenko et al., 2017). There could be an additional contribution from sea-ice CDOM (Norman et al., 2011; Xie et al., 2014; Gonçalves-Araujo et al., 2016), although the salinity- $\delta^{18} O$ mass balance suggests a stronger influence from meteoric waters as opposed to sea-ice melt (Hendry et al., 2019).

\subsubsection{Tracing bio-optical properties across boundary currents}

The glider sections bisected the West Greenland Current system three times during their deployment (Fig. 1). This system comprises a strong hydrographic front be- 
tween the coastal water and the offshore Irminger Water or SPMW. Several previous studies (Prater, 2002; Rykova, 2010) have documented that this system is subject to significant baroclinic instability, which can lead to the formation of enclosed eddies transporting shelf water into the ocean interior.

To assess qualitatively the degree to which terrestrial or shelf-derived material (e.g. FDOM) interacts with this unstable current system, geostrophic velocities were calculated using the glider density profiles and these estimates overlain on gridded FDOM concentration fields in Fig. 6. The boundary current at our study site has two or three surface intensified northward velocity cores in the top $200 \mathrm{~m}$ of the water column (Fig. 6), which may either reflect eddy or meander activity of the current itself, or possibly steering of the current by the complex topography of Godthäb Trough, the mouth of which is crossed by Section 2 (Hendry et al., 2019). Either way, while the highest FDOM concentrations are found on the shelf itself inshore of the main boundary current, there is significant evidence for enhanced FDOM being present across the boundary current in the top $100 \mathrm{~m}$ of the water column even into the deep basin of the Labrador Sea (e.g. Section 3, Fig. 6c, at $35 \mathrm{~km}$ along the baseline). Furthermore, the significant correlation between FDOM and calculated meltwater is maintained when the inshore profiles are excluded (e.g. for profiles in water depth $>900 \mathrm{~m}, \mathrm{r}=0.82, \mathrm{r}_{\text {sig }}=0.62$ for $99 \%$ significance for glider 331). This suggests that at least a proportion of the shelf-derived FDOM is transported across the boundary current into the interior of the Labrador Sea.

\subsubsection{FDOM in the Labrador Sea}

We used BGC-Argo data from the Irminger and Labrador Seas to assess regional relationships between FDOM and salinity. The BGC-Argo dataset was divided into different regions, and compared to the mean surface currents (Fig. 7). When floats enter the East Greenland Current from the Irminger Sea, there is already an existing freshwater signal with fairly high FDOM and CDOM $\left(\mathrm{K}_{d} 380\right)$, relative to the water just outside the current. As the floats swing around to the west coast of Greenland, they start to encounter water with much lower salinity and higher FDOM. However, without any float data from the east Greenland shelf, it is challenging to quantify the freshwater inputs from west Greenland relative to the inherited signal from the northern Irminger Sea or the Arctic. As the floats travel north, there is a strong input of fresh, high FDOM water around the margins of the Labrador Sea, with an attenuation of the signal into the central Labrador Sea. Our proxy for CDOM $\left(\mathrm{K}_{d} 380\right)$ tells a similar story to FDOM, although not identical, with some high $\mathrm{K}_{d}$, low FDOM measurements in the central Labrador Sea.

\subsubsection{Outlook}

The Labrador Sea basin has experienced some of the largest relative increases in freshwater flux from Greenland in recent decades with significant implications for deep water convection and basin-wide biogeochemistry. Whilst there are several sources of freshwater input into the Labrador Sea, most $(60 \%)$ of the observed increase in freshwater input into the Labrador Sea basin over recent decades originates from the Greenland ice sheet (Yang et al., 2016). In our study location, there is likely an accumulation of freshwater from along the West Greenland coast, in addition to input from East Greenland, observed in both physical data and models (Yang et al., 2016; Luo et al., 2016) and uraniumseries isotope tracers (Hendry et al., 2019). This accumulated freshwater eventually enters the Labrador Sea, over timescales of 3-12 months, via baroclinicity, eddy formation and local bathymetric steering (Yang et al., 2016), in addition to wind-driven Ekman transport (Schulze Chretien \& Frajka-Williams, 2018; Castelao et al., 2019). Ocean gliders with bio-optical sensors have the capability to provide the high-resolution observations that are required to understand these mesoscale processes, their sensitivity to future climatic forcing, and their role in supplying both freshwater and glacially-derived 
dissolved and particulate constituents to the open ocean. However, further work is required to make the use of bio-optical properties measured from autonomous platforms for tracking meltwater off West Greenland more robust. In particular, there is an outstanding question of the potential contribution of both freshwater, FDOM, and particulates from sources in addition to the GrIS. In particular, there is a need for better constraints on the input of FDOM from i) Arctic rivers and sea ice melt, transported via the Fram Strait and East Greenland Current, and ii) sedimentary sources. More information from the deployment off East Greenland of BGC-Argo floats and gliders, together with further processed-based studies of shelf-sediment interactions, would help to constrain the relative inputs of FDOM from the Arctic, East and West Greenland shelves.

\section{Conclusion}

Bio-optical measurements from gliders can be used to infer the distribution at high spatial and temporal resolution of glacial meltwaters and particle inputs, which originate off the glaciated margin of SE Greenland and cross the strong boundary currents into the open ocean. Optical backscatter signals are a result of suspended biomass, including algal cells, in addition to glacially sourced particles, which can be observed in the dataset when corrected for correlation with Chl a. Fluorescing dissolved organic matter (FDOM) broadly reflects the wider coloured dissolved organic matter (CDOM) pool, and shows strong spatial correlations with cold, fresh meltwaters, which comprise a significant proportion of meteoric (predominantly glacial) inputs, both in our glider observations and in BGC-Argo float data. Further work into the relationship between the fluorescing and scattering properties of particles and dissolved constituents using ocean gliders could provide a means to investigate the nature of glacial melt reaching the open ocean, and its spatial and temporal variability in other regions. 


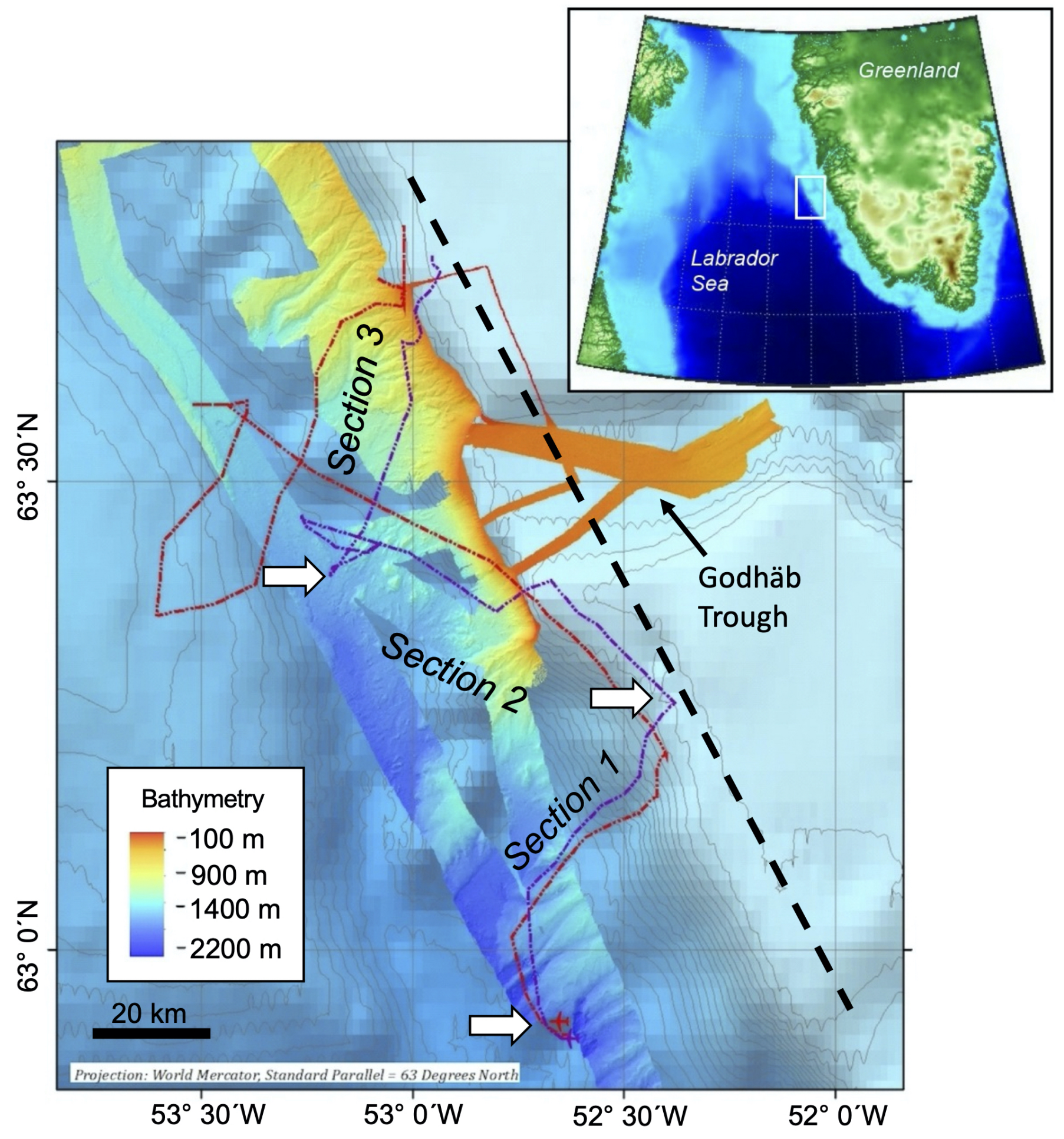

Figure 1. Map of area and glider tracks: Field study area and map of glider starting positions and tracks (dotted lines) for gliders 331 (purple) and 439 (red). Location of study area shown by white box in insert. Dashed line shows baseline used in Figure 2 for each of Section 1-3. Arrows mark the start of each section. Contoured ETOPO1 bathymetry data overlain with ship-board high-resolution bathymetry data from DY081 (Hoy et al., 2018). Produced in Mercator projection with a standard parallel of $63^{\circ} \mathrm{N}$.

This article is protected by copyright. All rights reserved. 

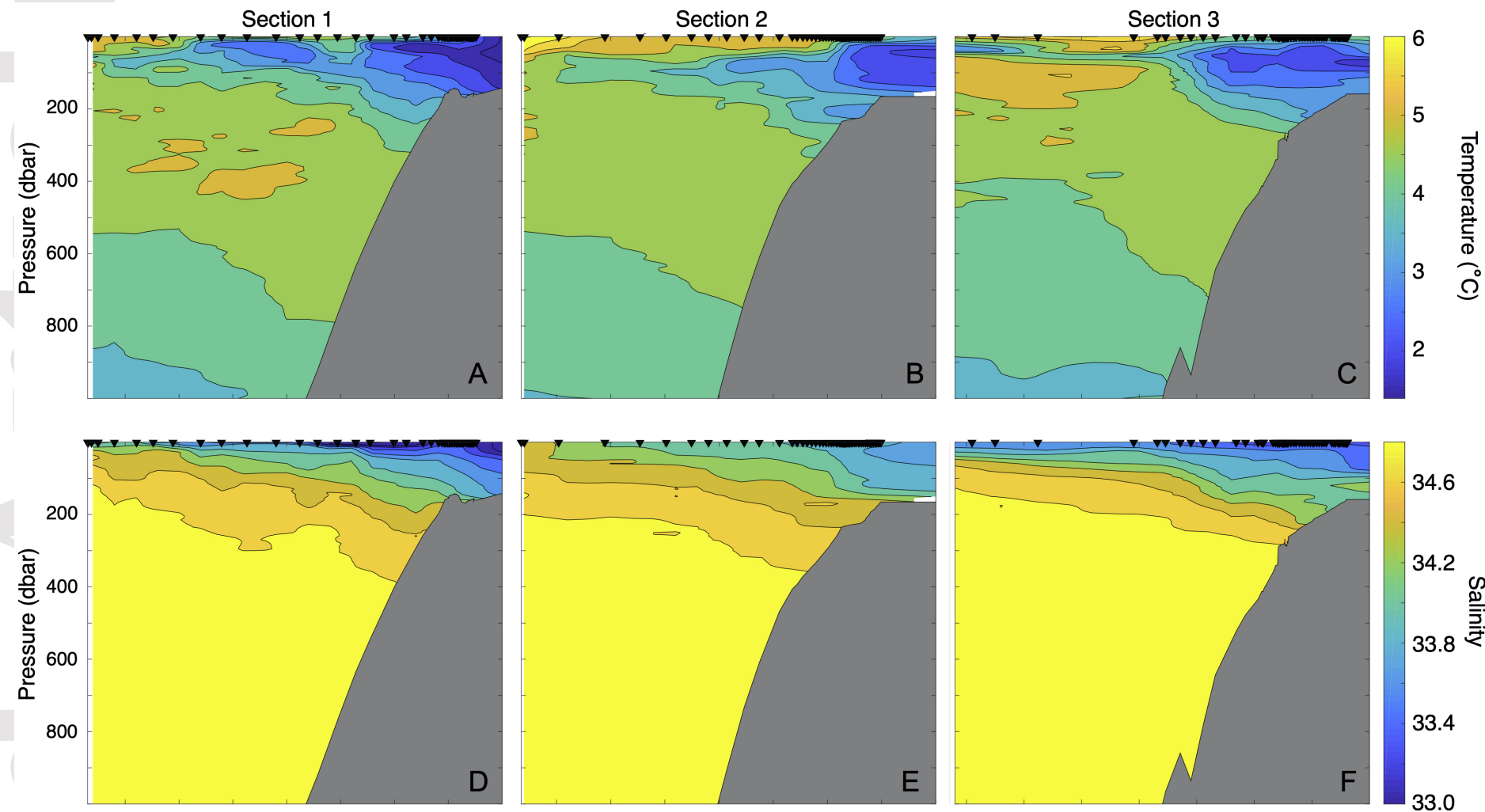

34.6

34.2

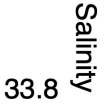

33.4

33.0
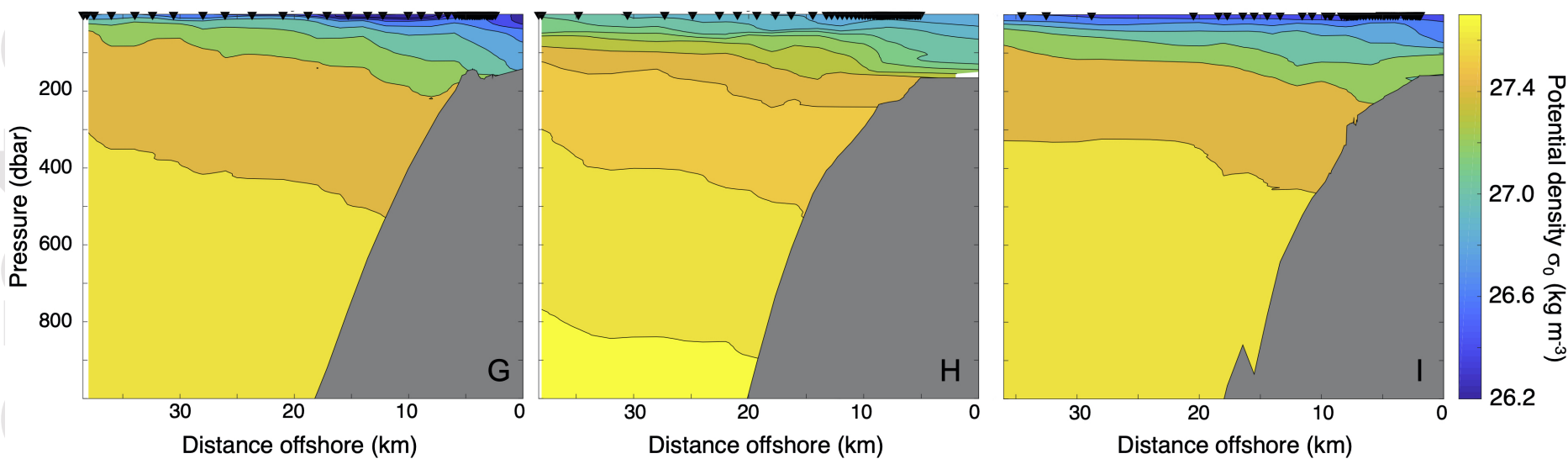

Figure 2. Temperature (A-C), salinity (D-F) and potential density (G-I) profiles from glider 331 along each section 1-3 from Figure 1. For temperature, salinity and potential density profiles of glider 439, see Supplementary Information (Fig. S1). Triangles show where the glider surfaced.

This article is protected by copyright. All rights reserved. 

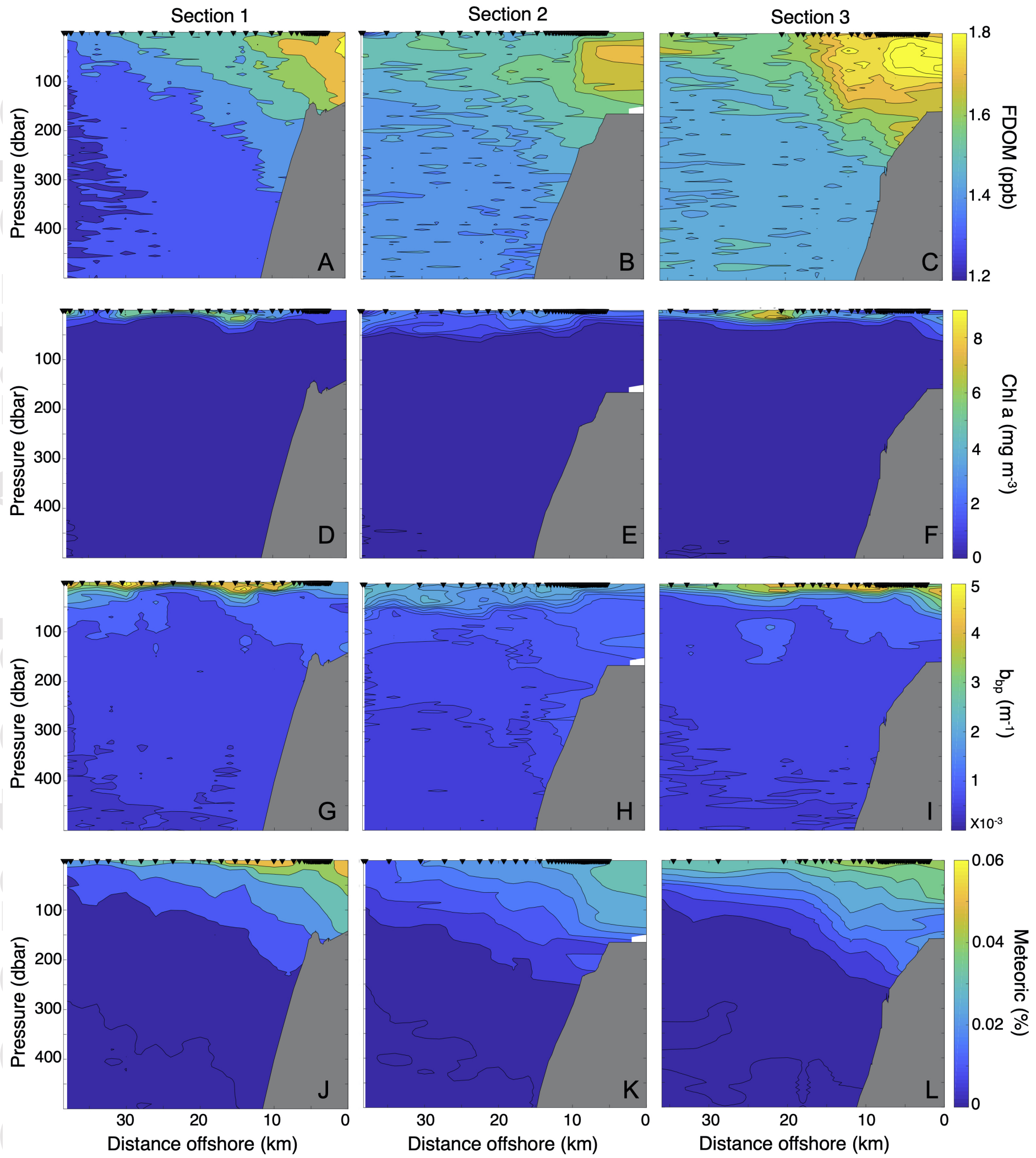

Figure 3. (A-C) FDOM, (D-F) quenching-corrected chlorophyll fluorescence, (G-I) Particulate backscattering coefficient $\left(\mathrm{b}_{b p}\right)$, and $(\mathrm{J}-\mathrm{L})$ calculated meltwater proportion for glider unit 331, along each section 1-3 from Figure 1. See main text for calculations. For plots of data from glider unit 439, see Supplementary Information (Fig. S4). Triangles show where the glider surfaced. $-14-$

This article is protected by copyright. All rights reserved. 

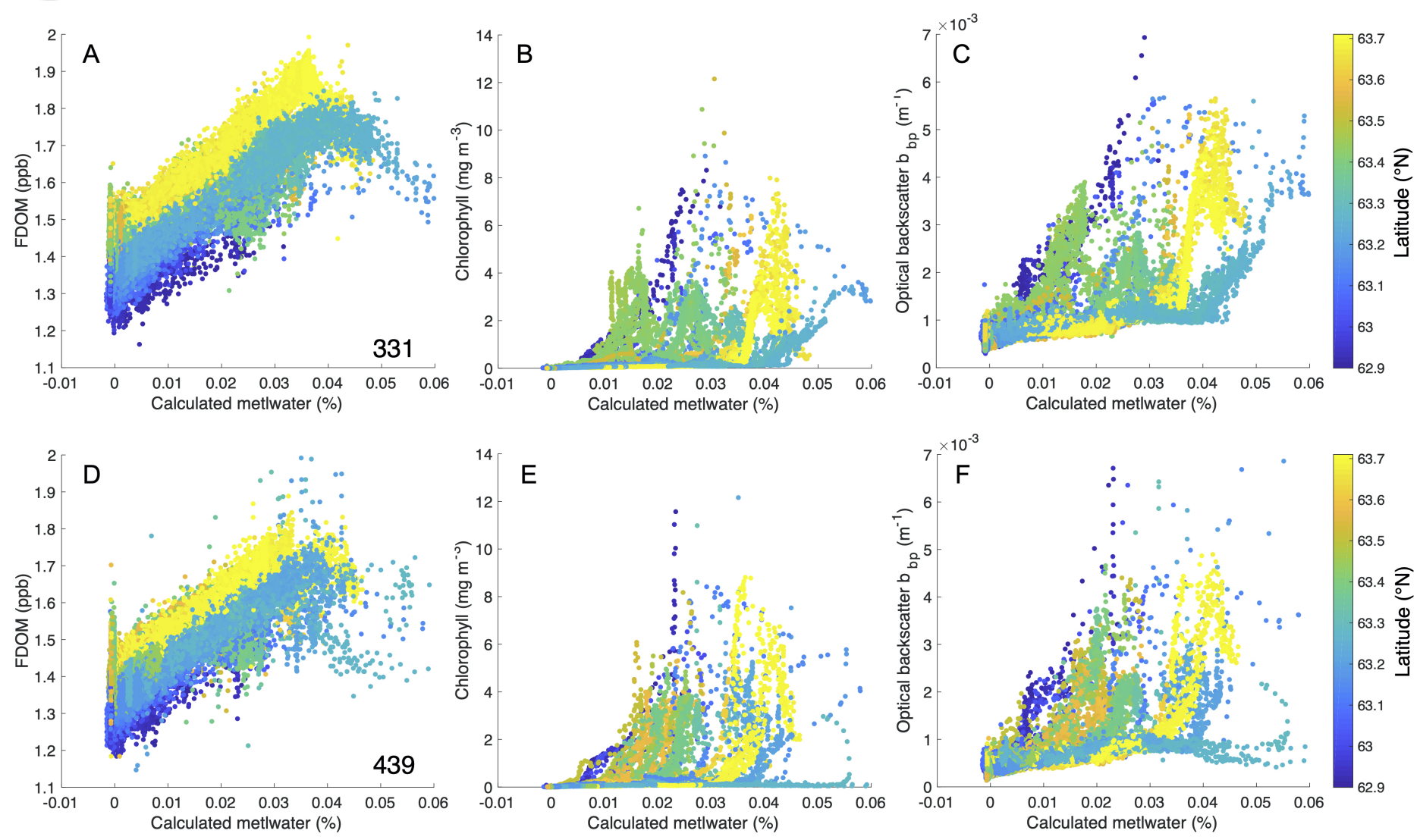

Figure 4. Correlations between calculated meltwater proportion and FDOM, quenchingcorrected chlorophyll and optical backscatter for unit 331 (A-C) and unit 439 (D-F). See main text for calculations (Equations 1 and 2). Colour scale indicates latitude. 

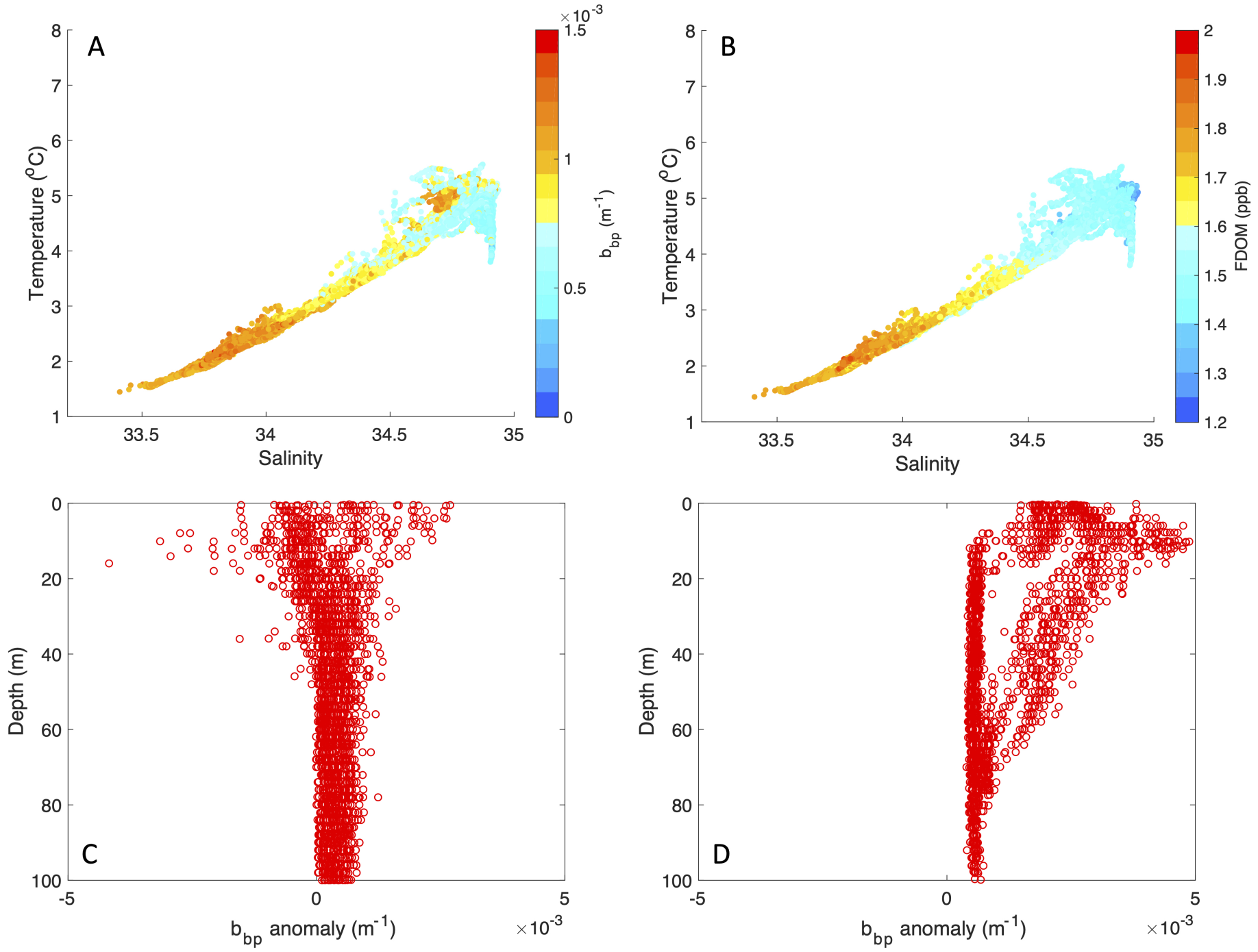

Figure 5. Cross plots for glider unit 331 of temperature and salinity, colour-scaled for $\mathrm{b}_{b p}$ (A) and FDOM (B), with data only from depth with uncorrected chlorophyll fluorescence $<0.2 \mathrm{mg} \mathrm{m}^{-3}$. Backscatter $\mathrm{b}_{b p}$ anomaly (difference between measured and predicted backscatter from correlation with chlorophyll, plotted for profiles in waters with bottom depth $>900 \mathrm{~m}$ (C) and $<100 \mathrm{~m}$ (D). See main text for full calculations (Equations 1 and 2). For plots of data from glider unit 439, see Supplementary Information (Fig. S6) 

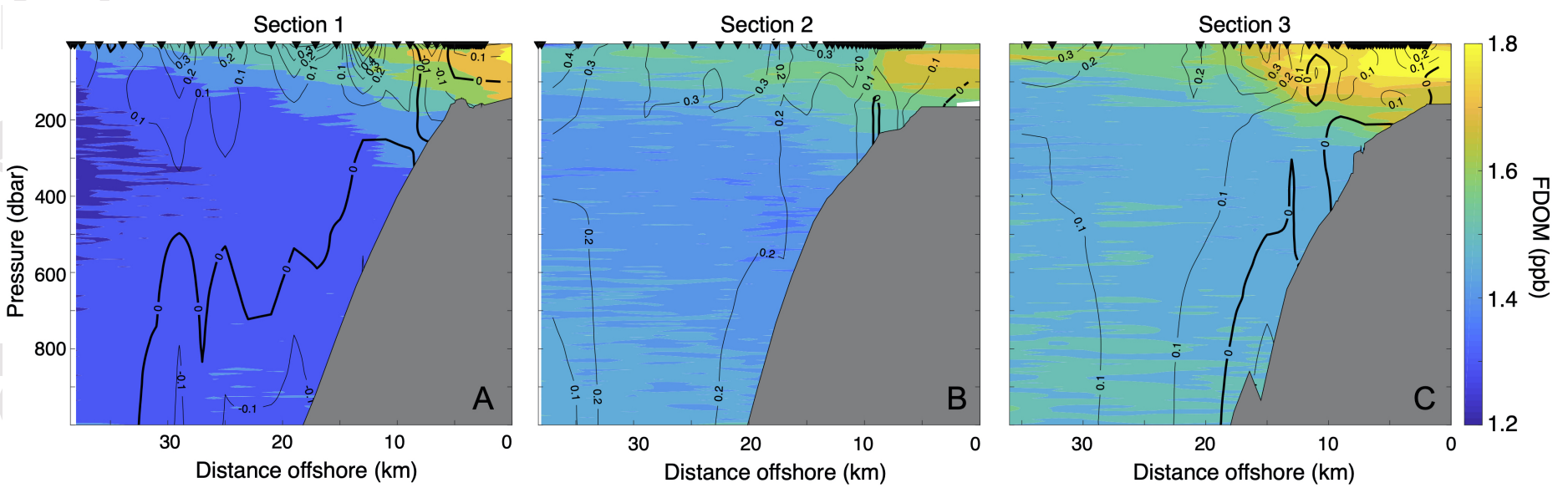

Figure 6. Gridded FDOM in colour (ppb) and velocities (in $\mathrm{m} \mathrm{s}^{-1}$ ) perpendicular to each glider section (shown in contours) for section 1 (A), section 2 (B), and section 3 (C) as shown in Figure 1 for glider 331 (positive northwards). For equivalent plots from glider 439, see Supplementary Information (Fig. S5). 

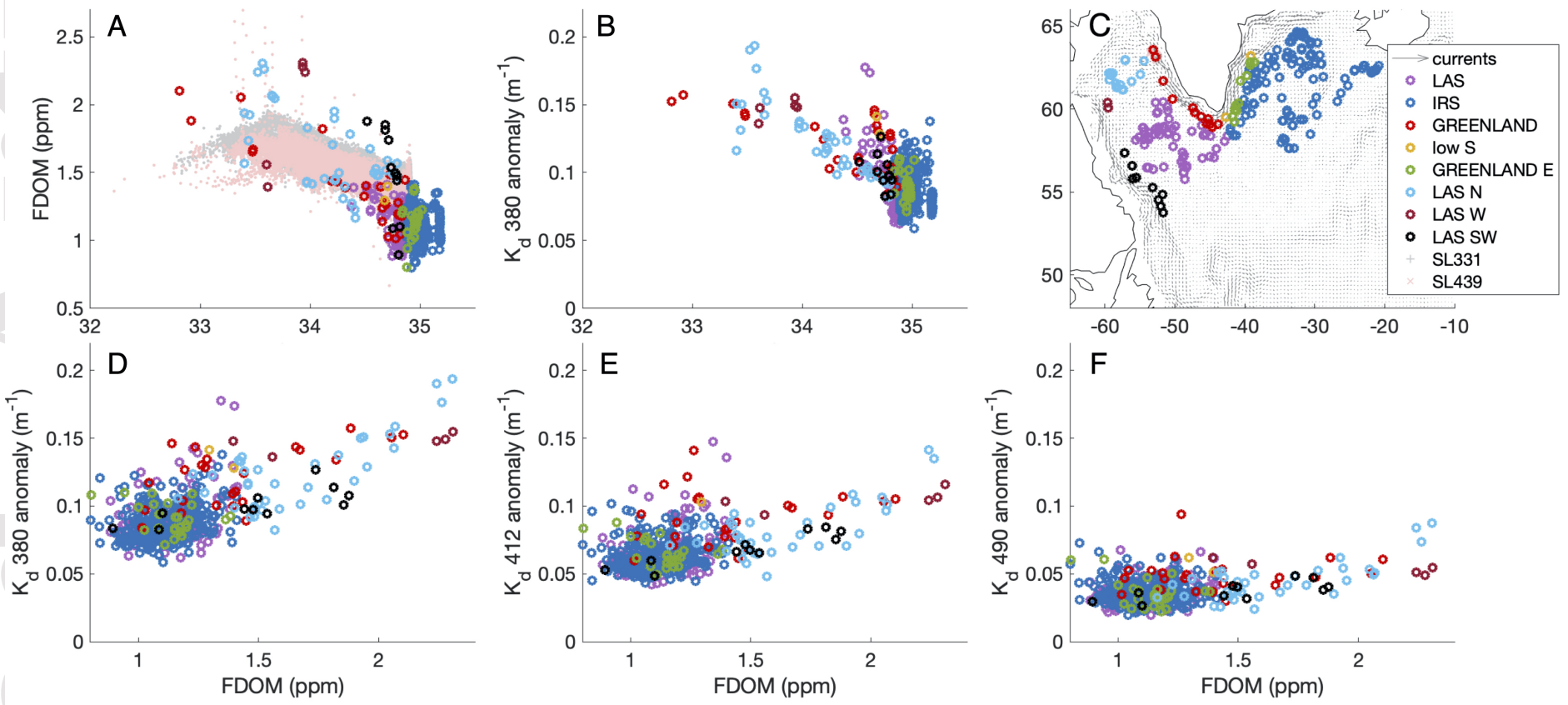

Figure 7. Regional relationships between FDOM, Salinity, and $\mathrm{K}_{d}$ from BGC-Argo floats. Individual panels show relationships between salinity and FDOM (A), salinity and $\mathrm{K}_{d} 380$ (B), FDOM and $\mathrm{K}_{d} 380$ (D), FDOM and $\mathrm{K}_{d} 412$ (E), FDOM and $\mathrm{K}_{d} 490$ (F). Panel C shows a map with the locations of the float and glider data. Pale symbols (pink and grey) represent glider data from this study. Other colours represent data from 10 BGC Argo floats. Float data all come from the top 10 to $100 \mathrm{~m}$ (where natural light is strong enough to measure $\mathrm{K}_{d}$ ). All data points with $\mathrm{Chl} \mathrm{a}>1 \mathrm{mg} \mathrm{m}^{-3}$ were eliminated to minimize possible influence of $\mathrm{Chl}$ a on $\mathrm{K}_{d}$. For the average regression slopes see the supplementary information (Fig. S8). 


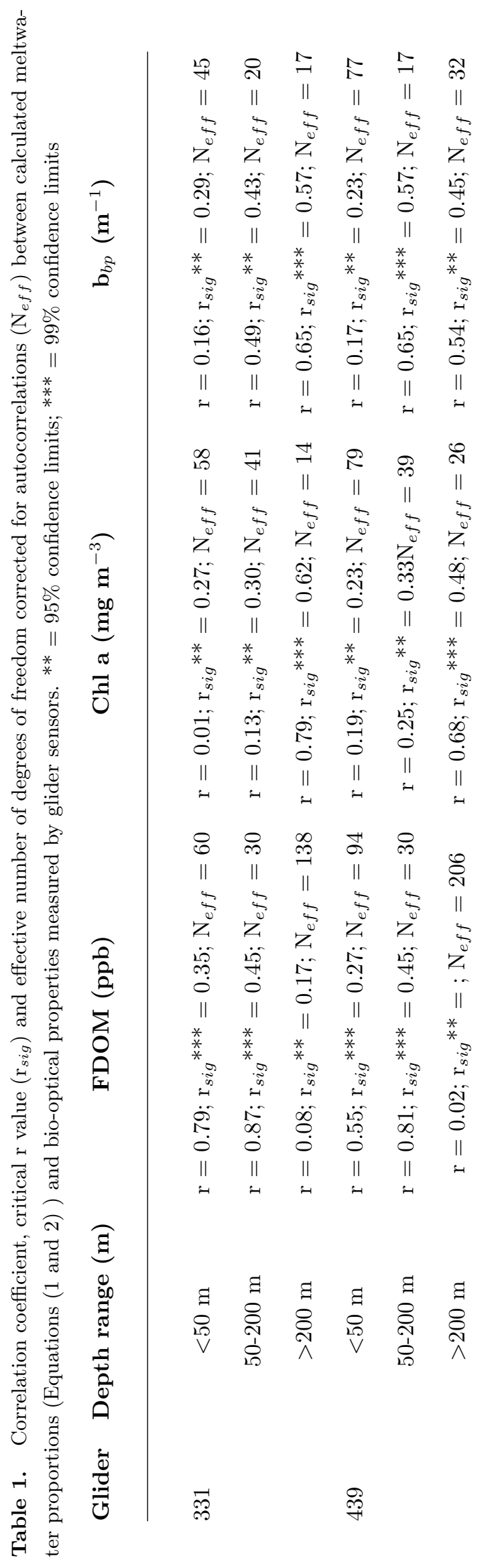




\section{Acknowledgments}

Many thanks to the Captain, crew, National Marine Facility technicians and all the scientists aboard RRS Discovery expedition DY081 for their assistance in deploying and retrieving the gliders, and project manager, Daniel Comben, National Oceanography Centre Southampton (NOCS). Many thanks to David White, Steve Woodward, and Candice Cameron for their assistance with glider preparation, deployment and piloting. Funding for DY081 was from the European Research Council (ERC Starting Grant 678371 ICY-LAB). JO is funded by NERC DTP studentship NE/L002582/1. Cruise report for DY081, CTD rosette and bottle data are available on PANGAEA (https:// doi.org/10.1594/ PANGAEA.896544); glider data are available on PANGAEA (https://doi.org/10.1594/ PANGAEA.931292). ETOPO1 data from NOAA National Geophysical Data Center. 2009: ETOPO1 1 Arc-Minute Global Relief Model. NOAA National Centers for Environmental Information. Accessed 04/08/2016. www.ncei.noaa.gov. BGC-Argo data were from Coriolis : ftp://ftp.ifremer.fr/ifremer/argo. Thanks to H. Claustre (CNRS) for curating the Argo float data. NB and SH were supported by a European Research Council Consolidator grant (GOCART, agreement number 724416) to SH. LM was funded by research programme VENI (016.Veni.192.150, NWO). Many thanks to the editor and two anonymous reviewers who provided constructive and detailed suggestions for improving the manuscript.

\section{References}

Alderkamp, A.-C., Buma, A. G., \& van Rijssel, M. (2007). The carbohydrates of phaeocystis and their degradation in the microbial food web. Biogeochemistry, 83(1-3), 99-118.

Andrés, E. D., Slater, D. A., Straneo, F., Otero, J., Das, S., \& Navarro, F. (2020). Surface emergence of glacial plumes determined by fjord stratification. The Cryosphere, 14(6), 1951-1969.

Arrigo, K. R., van Dijken, G. L., Castelao, R. M., Luo, H., Rennermalm, A. K., Tedesco, M., .. Y Yager, P. L. (2017). Melting glaciers stimulate large summer phytoplankton blooms in southwest greenland waters. Geophysical Research Letters, $44(12), 6278-6285$.

Bamber, J., Tedstone, A., King, M., Howat, I., Enderlin, E., van den Broeke, M., \& Noel, B. (2018). Land ice freshwater budget of the arctic and north atlantic oceans: 1. data, methods, and results. Journal of Geophysical Research: Oceans, 123(3), 1827-1837.

Bhatia, M. P., Kujawinski, E. B., Das, S. B., Breier, C. F., Henderson, P. B., \& Charette, M. A. (2013). Greenland meltwater as a significant and potentially bioavailable source of iron to the ocean. Nature Geoscience, 6(4), 274-278.

Biddle, L. C., Kaiser, J., Heywood, K. J., Thompson, A. F., \& Jenkins, A. (2015). Ocean glider observations of iceberg-enhanced biological production in the northwestern weddell sea. Geophysical Research Letters, 42(2), 459-465.

Carmack, E. C., Yamamoto-Kawai, M., Haine, T. W., Bacon, S., Bluhm, B. A., Lique, C., ... others (2016). Freshwater and its role in the arctic marine system: Sources, disposition, storage, export, and physical and biogeochemical consequences in the arctic and global oceans. Journal of Geophysical Research: Biogeosciences, $121(3), 675-717$.

Carvalho, F., Kohut, J., Oliver, M. J., Sherrell, R. M., \& Schofield, O. (2016). Mixing and phytoplankton dynamics in a submarine canyon in the west antarctic peninsula. Journal of Geophysical Research: Oceans, 121(7), 5069-5083.

Castelao, R. M., Luo, H., Oliver, H., Rennermalm, A. K., Tedesco, M., Bracco, A., ... Medeiros, P. M. (2019). Controls on the transport of meltwater from the southern greenland ice sheet in the labrador sea. Journal of Geophysical Research: Oceans, 124(6), 3551-3560.

Cetinić, I., Perry, M., D'asaro, E., Briggs, N., Poulton, N., Sieracki, M., \& Lee, C. 
(2015). A simple optical index shows spatial and temporal heterogeneity in phytoplankton community composition during the 2008 north atlantic bloom experiment. Biogeosciences, 12(7), 2179-2194.

Chu, V., Smith, L. C., Rennermalm, A. K., Forster, R., \& Box, J. (2012). Hydrologic controls on coastal suspended sediment plumes around the greenland ice sheet.

Cox, K., Stanford, J., McVicar, A., Rohling, E., Heywood, K. J., Bacon, S., ... Wilkinson, D. (2010). Interannual variability of arctic sea ice export into the east greenland current. Journal of Geophysical Research: Oceans, 115(C12).

Crusius, J., Schroth, A. W., Resing, J. A., Cullen, J., \& Campbell, R. W. (2017). Seasonal and spatial variabilities in northern gulf of alaska surface water iron concentrations driven by shelf sediment resuspension, glacial meltwater, a yakutat eddy, and dust. Global Biogeochemical Cycles, 31(6), 942-960.

Dmitrenko, I. A., Kirillov, S. A., Rudels, B., Babb, D. G., Pedersen, L. T., Rysgaard, S., ... Barber, D. G. (2017). Arctic ocean outflow and glacier-ocean interactions modify water over the wandel sea shelf (northeastern greenland). Ocean Science, 13(6), 1045-1060.

Egbert, G. D., \& Erofeeva, S. Y. (2002). Efficient inverse modeling of barotropic ocean tides. Journal of Atmospheric and Oceanic technology, 19(2), 183-204.

Enderlin, E. M., Howat, I. M., Jeong, S., Noh, M.-J., van Angelen, J. H., \& van den Broeke, M. R. (2014). An improved mass budget for the greenland ice sheet. Geophysical Research Letters, 41(3), 866-872.

Fan, S.-s., Yang, C.-j., Peng, S.-l., Li, K.-h., Xie, Y., \& Zhang, S.-y. (2013). Underwater glider design based on dynamic model analysis and prototype development. Journal of Zhejiang University SCIENCE C, 14(8), 583-599.

Felikson, D., Bartholomaus, T. C., Catania, G. A., Korsgaard, N. J., Kjær, K. H., Morlighem, M., ... others (2017). Inland thinning on the greenland ice sheet controlled by outlet glacier geometry. Nature Geoscience, 10(5), 366-369.

Frajka-Williams, E., Rhines, P. B., \& Eriksen, C. C. (2009). Physical controls and mesoscale variability in the labrador sea spring phytoplankton bloom observed by seaglider. Deep Sea Research Part I: Oceanographic Research Papers, $56(12), 2144-2161$.

Glenn, S., Jones, C., Twardowski, M., Bowers, L., Kerfoot, J., Kohut, J., .. . Schofield, O. (2008). Glider observations of sediment resuspension in a middle atlantic bight fall transition storm. Limnology and Oceanography, 53(5part2), 2180-2196.

Gonçalves-Araujo, R., Granskog, M. A., Bracher, A., Azetsu-Scott, K., Dodd, P. A., \& Stedmon, C. A. (2016). Using fluorescent dissolved organic matter to trace and distinguish the origin of arctic surface waters. Scientific reports, 6, 33978.

Hawkings, J. R., Wadham, J. L., Benning, L. G., Hendry, K. R., Tranter, M., Tedstone, A., ... Raiswell, R. (2017). Ice sheets as a missing source of silica to the polar oceans. Nature communications, 8(1), 1-10.

Hawkings, J. R., Wadham, J. L., Tranter, M., Raiswell, R., Benning, L. G., Statham, P. J., ... Telling, J. (2014). Ice sheets as a significant source of highly reactive nanoparticulate iron to the oceans. Nature communications, $5(1), 1-8$.

Helms, J. R., Stubbins, A., Ritchie, J. D., Minor, E. C., Kieber, D. J., \& Mopper, K. (2008). Absorption spectral slopes and slope ratios as indicators of molecular weight, source, and photobleaching of chromophoric dissolved organic matter. Limnology and Oceanography, 53(3), 955-969.

Hendry, K. R., Huvenne, V. A., Robinson, L. F., Annett, A., Badger, M., Jacobel, A. W., ... others (2019). The biogeochemical impact of glacial meltwater from southwest greenland. Progress in Oceanography, 176, 102126.

Hendry, K. R., Opher, J., Brearley, J. A., Briggs, N., Henson, S., \& Meredith, M. P. (2021). ICY-LAB DY081 Autonomous ocean glider data off Southwest Green- 
land [data set]. PANGAEA. Retrieved from https://doi.org/10.1594/ PANGAEA. 931292 doi: 10.1594/PANGAEA.931292

Hendry, K. R., Pyle, K. M., Barney Butler, G., Cooper, A., Fransson, A., Chierici, M., ... Dodd, P. A. (2018). Spatiotemporal variability of barium in arctic sea-ice and seawater. Journal of Geophysical Research: Oceans, 123(5), 3507-3522.

Holinde, L., \& Zielinski, O. (2015). Bio-optical characterization and light availability parametrization in two glacial melt water influenced estuary systems (west-greenland). Ocean Science Discussions, 12(4).

Holinde, L., \& Zielinski, O. (2016). Bio-optical characterization and light availability parameterization in uummannaq fjord and vaigat-disko bay (west greenland). Ocean Science, 12(1), 117-128.

Hood, E., Battin, T. J., Fellman, J., O’neel, S., \& Spencer, R. G. (2015). Storage and release of organic carbon from glaciers and ice sheets. Nature Geoscience, $8(2), 91-96$.

Hopwood, M. J., Bacon, S., Arendt, K., Connelly, D., \& Statham, P. (2015). Glacial meltwater from greenland is not likely to be an important source of fe to the north atlantic. Biogeochemistry, 124(1-3), 1-11.

Hopwood, M. J., Carroll, D., Dunse, T., Hodson, A., Holding, J. M., Iriarte, J. L., ... others (2020). How does glacier discharge affect marine biogeochemistry and primary production in the arctic? The Cryosphere, 14, 1347-1383.

Hoy, S. K., Hendry, K. R., \& Huvenne, V. A. I. $\quad$ (2018). North Atlantic EM122 multibeam swath bathymetry collected during RRS Discovery cruise DY081 (links to raw files and gridded data) [data set]. PANGAEA. Retrieved from https://doi.org/10.1594/PANGAEA.892825 doi: 10.1594/ PANGAEA.892825

Jenkins, A. (1999). The impact of melting ice on ocean waters. Journal of physical oceanography, 29(9), 2370-2381.

Kohut, J., Hunter, E., \& Huber, B. (2013). Small-scale variability of the crossshelf flow over the outer shelf of the ross sea. Journal of Geophysical Research: Oceans, 118(4), 1863-1876.

Koziorowska, K., Kuliński, K., \& Pempkowiak, J. (2018). Deposition, return flux, and burial rates of nitrogen and phosphorus in the sediments of two high-arctic fjords. Oceanologia, 60(4), 431-445.

Luek, J. L., Thompson, K. E., Larsen, R. K., Heyes, A., \& Gonsior, M. Sulfate reduction in sediments produces high levels of chromophoric dissolved organic matter. Scientific reports, $7(1), 1-8$.

Lund-Hansen, L. C., Andersen, T. J., Nielsen, M. H., \& Pejrup, M. (2010). Suspended matter, chl-a, cdom, grain sizes, and optical properties in the arctic fjord-type estuary, kangerlussuaq, west greenland during summer. Estuaries and coasts, 33(6), 1442-1451.

Luo, H., Castelao, R. M., Rennermalm, A. K., Tedesco, M., Bracco, A., Yager, P. L., \& Mote, T. L. (2016). Oceanic transport of surface meltwater from the southern greenland ice sheet. Nature Geoscience, 9(7), 528-532.

Mascarenhas, V. J., \& Zielinski, O. (2019). Hydrography-driven optical domains in the vaigat-disko bay and godthabsfjord: effects of glacial meltwater discharge. Frontiers in Marine Science, 6, 335.

McCartney, M. S., \& Talley, L. D. (1982). The subpolar mode water of the north atlantic ocean. Journal of Physical Oceanography, 12(11), 1169-1188.

McGrath, D., Steffen, K., Overeem, I., Mernild, S. H., Hasholt, B., \& Van Den Broeke, M. (2010). Sediment plumes as a proxy for local ice-sheet runoff in kangerlussuaq fjord, west greenland. Journal of Glaciology, 56(199), 813821.

Meire, L., Meire, P., Struyf, E., Krawczyk, D., Arendt, K., Yde, J., .. Meysman, F. (2016). High export of dissolved silica from the greenland ice sheet. Geophysi- 
cal Research Letters, 43(17), 9173-9182.

Merckelbach, L., Smeed, D., \& Griffiths, G. (2010). Vertical water velocities from underwater gliders. Journal of Atmospheric and Oceanic Technology, 27(3), 547-563.

Meredith, M. P., Brandon, M. A., Wallace, M. I., Clarke, A., Leng, M. J., Renfrew, I. A., ... King, J. C. (2008). Variability in the freshwater balance of northern marguerite bay, antarctic peninsula: results from $\delta 18 \mathrm{o}$.

Deep Sea Research Part II: Topical Studies in Oceanography, 55(3-4), 309-322.

Meredith, M. P., Sommerhorn, M., et al. (2019). Polar regions.

Meyer, D. (2016). Glider technology for ocean observations: A review. Ocean Science Discussions, 1-26.

Miles, T., Lee, S. H., Wåhlin, A., Ha, H. K., Kim, T. W., Assmann, K. M., \& Schofield, O. (2016). Glider observations of the dotson ice shelf outflow. Deep Sea Research Part II: Topical Studies in Oceanography, 123, 16-29.

Miles, T., Seroka, G., Kohut, J., Schofield, O., \& Glenn, S. (2015). Glider observations and modeling of sediment transport in hurricane sandy. Journal of Geophysical Research: Oceans, 120(3), 1771-1791.

Mopper, K., Kieber, D. J., \& Stubbins, A. (2015). Marine photochemistry of organic matter: processes and impacts. In Biogeochemistry of marine dissolved organic matter (pp. 389-450). Elsevier.

Murray, C., Markager, S., Stedmon, C. A., Juul-Pedersen, T., Sejr, M. K., \& Bruhn, A. (2015). The influence of glacial melt water on bio-optical properties in two contrasting greenlandic fjords. Estuarine, Coastal and Shelf Science, 163, $72-83$.

Ng, H. C., Cassarino, L., Pickering, R. A., Woodward, E. M. S., Hammond, S. J., \& Hendry, K. R. (2020). Sediment efflux of silicon on the greenland margin and implications for the marine silicon cycle. Earth and Planetary Science Letters, 529, 115877.

Norman, L., Thomas, D. N., Stedmon, C. A., Granskog, M. A., Papadimitriou, S., Krapp, R. H., .. Dieckmann, G. S. (2011). The characteristics of dissolved organic matter (dom) and chromophoric dissolved organic matter (cdom) in antarctic sea ice. Deep Sea Research Part II: Topical Studies in Oceanography, 58(9-10), 1075-1091.

Oliver, H., Luo, H., Castelao, R. M., van Dijken, G. L., Mattingly, K. S., Rosen, J. J., . . others (2018). Exploring the potential impact of greenland meltwater on stratification, photosynthetically active radiation, and primary production in the labrador sea. Journal of Geophysical Research: Oceans, 123(4), 2570-2591.

Organelli, E., Claustre, H., Bricaud, A., Barbieux, M., Uitz, J., D’Ortenzio, F., \& Dall'Olmo, G. (2017). Bio-optical anomalies in the world's oceans: An investigation on the diffuse attenuation coefficients for downward irradiance derived from biogeochemical argo float measurements. Journal of Geophysical Research: Oceans, 122(5), 3543-3564.

Pain, A. J., Martin, J. B., Martin, E. E., Rahman, S., \& Ackermann, P. (2020). Differences in the quantity and quality of organic matter exported from greenlandic glacial and deglaciated watersheds. Global Biogeochemical Cycles, 34(10), e2020GB006614.

Pan, B. J., Vernet, M., Reynolds, R. A., \& Mitchell, B. G. (2019). The optical and biological properties of glacial meltwater in an antarctic fjord. PloS one, 14(2), e0211107.

Prater, M. D. (2002). Eddies in the labrador sea as observed by profiling rafos floats and remote sensing. Journal of Physical Oceanography, 32(2), 411-427.

Proshutinsky, A., Dukhovskoy, D., Timmermans, M., Krishfield, R., \& Bamber, J. (2015). Arctic circulation regimes, philos. In Roy. soc. a (Vol. 373, pp. 10-1098). 
Rudnick, D. L. (2016). Ocean research enabled by underwater gliders. Annual review of marine science, 8, 519-541.

Rykova, T. A. (2010). The seasonal and interannual variability of the west greenland current system in the labrador sea (Unpublished doctoral dissertation). Massachusetts Institute of Technology.

Rysgaard, S., Boone, W., Carlson, D., Sejr, M., Bendtsen, J., Juul-Pedersen, T., ... Mortensen, J. (2020). An updated view on water masses on the panwest greenland continental shelf and their link to proglacial fjords. Journal of Geophysical Research: Oceans, 125(2), e2019JC015564.

Schofield, O., Miles, T., Alderkamp, A.-C., Lee, S., Haskins, C., Rogalsky, E., ... Yager, P. L. (2015). In situ phytoplankton distributions in the amundsen sea polynya measured by autonomous gliders. Elementa-Science Of The Anthropocene, 3,1 .

Schulze Chretien, L. M., \& Frajka-Williams, E. (2018). Wind-driven transport of fresh shelf water into the upper $30 \mathrm{~m}$ of the labrador sea. Ocean Science, $14(5)$, $1247-1264$.

Shepherd, A., Ivins, E., Rignot, E., Smith, B., van den Broeke, M., Velicogna, I., ... others (2020). Mass balance of the greenland ice sheet from 1992 to 2018. Nature, 579(7798), 233-239.

Stedmon, C. A., Granskog, M. A., \& Dodd, P. A. (2015). An approach to estimate the freshwater contribution from glacial melt and precipitation in e ast g reenland shelf waters using colored dissolved organic matter (cdom). Journal of Geophysical Research: Oceans, 120(2), 1107-1117.

Stedmon, C. A., \& Markager, S. (2001). The optics of chromophoric dissolved organic matter (cdom) in the greenland sea: An algorithm for differentiation between marine and terrestrially derived organic matter. Limnology and Oceanography, 46(8), 2087-2093.

Stedmon, C. A., Thomas, D. N., Granskog, M., Kaartokallio, H., Papadimitriou, S., \& Kuosa, H. (2007). Characteristics of dissolved organic matter in baltic coastal sea ice: allochthonous or autochthonous origins? Environmental Science 83 Technology, 41(21), 7273-7279.

Sullivan, J. M., Twardowski, M. S., Ronald, J., Zaneveld, V., \& Moore, C. C. (2013). Measuring optical backscattering in water. In Light scattering reviews 7 (pp. 189-224). Springer.

Swart, S., Thomalla, S. J., \& Monteiro, P. (2015). The seasonal cycle of mixed layer dynamics and phytoplankton biomass in the sub-antarctic zone: A highresolution glider experiment. Journal of Marine Systems, 147, 103-115.

Tedstone, A. J., \& Arnold, N. S. (2012). Automated remote sensing of sediment plumes for identification of runoff from the greenland ice sheet. Journal of Glaciology, 58(210), 699-712.

Thomalla, S. J., Ogunkoya, A. G., Vichi, M., \& Swart, S. (2017). Using optical sensors on gliders to estimate phytoplankton carbon concentrations and chlorophyll-to-carbon ratios in the southern ocean. Frontiers in Marine Science, 4,34 .

van den Broeke, M., Box, J., Fettweis, X., Hanna, E., Noël, B., Tedesco, M., .. van Kampenhout, L. (2017). Greenland ice sheet surface mass loss: Recent developments in observation and modeling. Current Climate Change Reports, 3(4), 345-356.

Vick-Majors, T. J., Michaud, A. B., Skidmore, M. L., Turetta, C., Barbante, C., Christner, B. C., ... others (2020). Biogeochemical connectivity between freshwater ecosystems beneath the west antarctic ice sheet and the sub-ice marine environment. Global Biogeochemical Cycles, 34(3), no-no.

Wassmann, P., Vernet, M., Mitchell, B. G., \& Rey, F. (1990). Mass sedimentation of phaeocystis pouchetii in the barents sea. Marine Ecology Progress Series, 183195. 
Xie, H., Aubry, C., Zhang, Y., \& Song, G. (2014). Chromophoric dissolved organic matter (cdom) in first-year sea ice in the western canadian arctic. Marine Chemistry, 165, 25-35.

Yang, Q., Dixon, T. H., Myers, P. G., Bonin, J., Chambers, D., Van Den Broeke, M., ... Mortensen, J. (2016). Recent increases in arctic freshwater flux affects labrador sea convection and atlantic overturning circulation. Nature communications, 7(1), 1-8.

Zaborska, A., Włodarska-Kowalczuk, M., Legeżyńska, J., Jankowska, E., Winogradow, A., \& Deja, K. (2018). Sedimentary organic matter sources, benthic consumption and burial in west spitsbergen fjords-signs of maturing of arctic fjordic systems? Journal of Marine Systems, 180, 112-123.

Zhang, X., Hu, L., \& He, M.-X. (2009). Scattering by pure seawater: effect of salinity. Optics Express, 17(7), 5698-5710. 